\title{
EFEKTIVITAS JALUR-JALUR TRANSMISI KEBIJAKAN MONETER DI INDONESIA DENGAN SASARAN TUNGGAL INFLASI
}

\author{
Mohamad Yusuf \\ Sekretariat Direktorat Jenderal Perbendaharaan \\ Alamat Korespondensi: mohamad.yusuf84@kemenkeu.go.id
}

\section{INFORMASI ARTIKEL}

\section{Diterima Pertama}

19 Mei 2016

\section{Dinyatakan Diterima}

15 Juli 2016

\section{KATA KUNCI:}

Monetary Policy, Macroeconomic Policy, Inflation Targeting Framework (ITF), Interest Rate, Exchange Rate, Vector Auto Regression (VAR) Model.

KLASIFIKASI JEL:

C5, E4, E5, E6, 01

\begin{abstract}
ABSTRAK
The purpose of this study is to examine the effectiveness of four monetary policy transmission channels, i.e. direct monetary, interest rate, credit, and exchange rate, on inflation rate in Indonesia as the single target, and to determine the most suitable variables for operational target on the most effective channel. The quantitative research method applied in this study used Vector Auto Regression (VAR) model to analyze the effectiveness of monetary policy transmission channels in Indonesia in the period from the first quarter of 2000 to the third quater of 2013. The data were taken from Indonesia Finance Statistics (SEKI), Bank Indonesia Annual Reports, IMF Finance Statistics, and Publication of the Central Bureau Statistics. The results show that the interest rate channel is the most effective method compared with the other channels. The analysis done through testing impulse response and variance decomposition tests indicates the reliability of interest rate channel in reaching the inflation target. The interest rate of the interbank money market is the most suitable indicator for operational target of the interest rate channel. Test results using path impluse response method indicates that shocks of RPUAB get a strong and fast response.
\end{abstract}

Tujuan Penelitian ini untuk mengetahui di antara keempat jalur transmisi kebijakan moneter, yaitu jalur moneter langsung, jalur suku bunga, jalur kredit, dan jalur nilai tukar yang lebih efektif dalam implementasi kebijakan moneter dengan sasaran tunggal inflasi di Indonesia dan mengetahui variabel yang paling cocok digunakan sebagai sasaran operasional pada jalur yang paling efektif. Metode penelitian yang digunakan adalah penelitian kuantitatif dengan menggunakan analisis Vector Autoregression (VAR). Penelitian ini merupakan studi kasus untuk Indonesia periode tahun 2000 triwulan I sampai dengan tahun 2013 triwulan III. Data bersumber dari Statistik Ekonomi dan Keuangan Indonesia (SEKI), Laporan Tahunan Bank Indonesia, IMF Finance Statistics, dan publikasi Badan Pusat Statistik. Hasil penelitian menunjukkan bahwa jalur suku bunga merupakan jalur yang paling efektif dibanding dengan jalur-jalur lainnya. Analisis yang dilakukan melalui uji impulse response dan uji variance decomposition menggambarkan keandalan penggunaan jalur suku bunga dalam mencapai sasaran akhir inflasi, terlihat dari respon yang diberikan oleh inflasi dan varians dari variabel-variabel yang terlibat dalam jalur ini. Pengujian pada jalur suku bunga menunjukkan bahwa shock RPUAB mendapatkan respon yang kuat dan juga cepat dari inflasi sehingga cocok digunakan sebagai sasaran operasional dalam mencapai sasaran akhir inflasi. 


\section{PENDAHULUAN}

Undang-undang (UU) Bank Indonesia No. 23 tahun 1999 sebagaimana telah diamandemen dengan UU No. 3 tahun 2004 pada pasal 7 menyatakan bahwa tujuan Bank Indonesia (BI) adalah mencapai dan memelihara kestabilan nilai Rupiah yang merupakan single objective Bank Indonesia. Pada UU tersebut Bank Indonesia diberikan kewenangan penuh dalam melaksanakan kebijakan moneter untuk mengendalikan nilai Rupiah. Kebijakan moneter dengan tujuan stabilisasi nilai Rupiah mulai diterapkan di Indonesia sejak tahun 2000, namun secara formal diterapkan mulai Juli tahun 2005. Tujuan tunggal kebijakan moneter BI tersebut terangkum dalam kerangka kerja penargetan inflasi (Inflation Targeting Framework).

Penargetan inflasi adalah sebuah kerangka kerja kebijakan moneter dengan ciri adanya pernyataan resmi dari bank sentral bahwa tujuan akhir kebijakan moneter adalah mencapai dan menjaga tingkat inflasi yang rendah, dan mengumumkan target inflasi tersebut kepada publik (Warjiyo dan Solikin, 2003). ${ }^{1}$ Inflation Targeting Framework (ITF) diyakini dapat membantu bank sentral untuk mencapai dan memelihara kestabilan harga dengan menentukan sasaran kebijakan moneter secara eksplisit berdasarkan proyeksi dan target inflasi tertentu.

Tabel 1. Negara-negara yang telah Menerapkan ITF

\begin{tabular}{|l|c|l|c|}
\hline \multicolumn{1}{|c|}{ Negara } & Tahun & \multicolumn{1}{c|}{ Negara } & Tahun \\
\hline Selandia Baru & 1990 & Swedia & 1993 \\
\hline Kanada & 1991 & Spanyol & 1995 \\
\hline Israel & 1991 & Thailand & 1997 \\
\hline Inggris & 1992 & Korea & 1998 \\
\hline Australia & 1993 & Filipina & 2002 \\
\hline Finlandia & 1993 & Indonesia & 2005 \\
\hline
\end{tabular}

Sumber: Cavoli (2010), Hakim (2001).

Dalam kerangka inflation targeting, perumusan dan pelaksanaan kebijakan moneter oleh bank sentral bersifat forward-looking, yang artinya bahwa kebijakan moneter yang ditempuh pada saat ini sebagai langkah antisipatif dalam mencapai target inflasi di masa yang akan datang. Kebijakan moneter yang berorientasi pada masa depan disebabkan oleh adanya selang waktu (time lag) dari pengaruh perkembangan suatu variabel ekonomi terhadap variabel ekonomi lainnya. Dengan adanya efek tunda (lag) dalam kebijakan moneter, mendorong perlunya memahami mekanisme transmisi kebijakan moneter terhadap kegiatan ekonomi riil, yang mana

1 P. Warjiyo dan Solikin, Kebijakan Moneter di Indonesia, Seri Kebanksentralan No. 6, PPSK, (Jakarta: Bank Indonesia, 2003). mekanisme tersebut dapat dilalui dengan berbagai jalur atau saluran.

Transmisi kebijakan moneter menuju sasaran akhir berlangsung dengan selang waktu yang lama dan bervariasi. Hal ini terkait dengan pola hubungan antara berbagai variabel ekonomi dan keuangan yang selalu berubah sejalan dengan perkembangan ekonomi di negara bersangkutan. Efektivitas jalurjalur transmisi kebijakan moneter menjadi sangat penting, karena hal tersebut digunakan untuk mengetahui saluran transmisi mana yang paling dominan dalam ekonomi untuk dipergunakan sebagai dasar dalam perumusan strategi kebijakan moneter. Juga untuk mengetahui seberapa kuat dan lamanya tenggat waktu masing-masing saluran transmisi tersebut bekerja. Hal ini penting untuk menentukan variabel ekonomi dan keuangan mana yang paling kuat dijadikan leading indicators terhadap pergerakan inflasi serta variabel mana sebagai indikator untuk penentuan sasaran operasional kebijakan moneter (Warjiyo, 2004).

Hubungan antara instrumen pengendalian moneter dengan sasaran akhir kebijakan moneter bersifat tidak langsung dan kompleks serta membutuhkan waktu yang relatif panjang. Oleh karena itu, para ahli dan praktisi di bidang moneter menambahkan indikator yang disebut dengan sasaran operasional. Sasaran tersebut merupakan indikator guna menilai kinerja keberhasilan kebijakan moneter dan dapat digunakan untuk mengarahkan tercapainya sasaran akhir. Penelitian ini akan menganalasis empat jalur transmisi kebijakan moneter, yaitu jalur moneter langsung, jalur suku bunga, jalur kredit, dan jalur nilai tukar untuk mengetahui jalur mana yang paling efektif dalam implementasi kebijakan moneter dengan sasaran tunggal inflasi di Indonesia. Dari jalur yang paling efektif tersebut juga akan dicari variabel yang paling cocok digunakan sebagai sasaran operasional.

\section{KERANGKA TEORI DAN PENGEMBANG- AN HIPOTESIS}

\subsection{Inflasi}

Pengertian umum inflasi adalah proses kenaikan harga barang-barang secara umum yang berlangsung terus menerus, bukan hanya satu macam barang dan bukan dalam waktu sesaat. Inflasi menggambarkan kenaikan tingkat harga rata-rata yang tidak diimbangi dengan kenaikan yang proporsional dari barang dan jasa yang dikonsumsi. Secara garis besar ada tiga teori mengenai inflasi yaitu teori kuantitas, teori Keynes, dan teori strukturalis (Boediono, 1982). ${ }^{2}$ Teori kuantitas lebih menyoroti peranan

2 Boediono, Ekonomi Makro. Seri Sinopsis Pengantar Ilmu Ekonomi No. 2. Edisi Ketiga, 
dalam proses terjadinya inflasi yang disebabkan dua faktor, yaitu jumlah uang beredar dan ekspektasi atau harapan masyarakat mengenai kenaikan harga. Menurut teori Keynes, inflasi terjadi karena masyarakat ingin hidup di luar batas kemampuan ekonominya. Hal ini terjadi karena masyarakat mengetahui keinginannya dan menjadikan keinginan tersebut dalam bentuk permintaan yang efektif terhadap barang. Teori strukturalis juga disebut dengan teori inflasi jangka panjang, karena menyoroti sebab-sebab munculnya inflasi yang berasal dari kekakuan struktur ekonomi terutama yang terjadi di negara berkembang.

\subsection{Kebijakan Moneter}

Kebijakan moneter merupakan kebijakan otoritas moneter atau bank sentral dalam bentuk pengendalian besaran moneter untuk mencapai perkembangan kegiatan perekonomian yang diinginkan. Dalam prakteknya yang disebut dengan perkembangan kegiatan perekonomian yang diinginkan tersebut adalah stabilitas ekonomi makro yang tercermin pada stabilitas harga (rendahnya laju inflasi), membaiknya perkembangan output riil (pertumbuhan ekonomi), serta cukup luasnya lapangan kerja yang tersedia. ${ }^{3}$

\subsection{Inflation Targeting}

Inflasi merupakan indikator stabilitas perekonomian yang menjadi pusat perhatian dalam kebijakan makro ekonomi sehingga laju perubahannya selalu diusahakan berada pada tingkat yang rendah dan stabil. Pengendalian inflasi di Indonesia dilakukan dengan menerapkan strategi penargetan inflasi (inflation targeting). Dalam perkembangannya, inflation targeting mulai digunakan sebagai alat yang efektif untuk mempertahankan tingkat harga yang rendah dan stabil, hal tersebut telah mendorong sejumlah otoritas moneter di beberapa negara untuk meneliti kemungkinan penerapannya.

\subsection{Mekanisme Transmisi Kebijakan Moneter}

Bank Indonesia menggunakan kebijakan BI Rate sebagai instrumen kebijakan utama untuk mempengaruhi aktivitas kegiatan perekonomian dengan tujuan akhir pencapaian sasaran inflasi. Mekanisme bekerjanya perubahan BI Rate sampai mempengaruhi inflasi tersebut sering disebut dengan istilah mekanisme transmisi kebijakan moneter (MTM). Taylor (1995) menyatakan bahwa mekanisme transmisi kebijakan moneter merupakan jalur-jalur yang dilalui oleh kebijakan untuk dapat

(Yogyakarta: Badan Penerbit Fakultas Ekonomi (BPFE) UGM, 1982). mempengaruhi sasaran akhir kebijakan moneter yaitu pendapatan nasional dan inflasi. ${ }^{4}$ Mekanisme transmisi kebijakan moneter terjadi melalui interaksi antara Bank Sentral, perbankan dan sektor keuangan, serta sektor riil.

\subsection{Penelitian Tedahulu}

Terdapat penelitian-penelitian sebelumnya yang dapat digunakan sebagai referensi dalam penelitian ini. Wulandari (2012) meneliti apakah jalur kredit dan jalur suku bunga memainkan peran penting dalam mekanisme transmisi kebijakan moneter di Indonesia dengan menggunakan model Structural Vector Autoregression (SVAR). ${ }^{5}$ Hasil dari penelitian tersebut menunjukkan bahwa jalur suku bunga memainkan peran penting pada mekanisme transmisi kebijakan moneter dalam menjaga inflasi, sedangkan jalur kredit secara efektif mempengaruhi pertumbuhan ekonomi. Natsir (2011) melakukan penelitian untuk menganalisis dan membuktikan efektivitas jalur suku bunga dalam MTM di Indonesia serta menganalisis dan membuktikan peranan suku bunga pasar uang antar bank sebagai sasaran operasional kebijakan moneter di Indonesia. ${ }^{6}$ Model penelitian yang digunakan adalah model Vector Auto Regression (VAR). Hasil kajian dimaksud menunjukkan bahwa MTM melalui jalur suku bunga efektif mewujudkan sasaran akhir kebijakan moneter di Indonesia periode 1990:2-2007:1. Variabel utama jalur ini yaitu RPUAB berfungsi secara efektif sebagai sasaran operasional kebijakan moneter di Indonesia.

Penelitian dilakukan oleh Maski (2005) untuk membuktikan bahwa jalur tingkat bunga lebih efektif dibandingkan jalur moneter, membuktikan bahwa jalur nilai tukar tidak efektif, dan untuk mengetahui sektor mana yang dominan pengaruhnya pada jalur kredit perbankan dengan menggunakan model VAR. ${ }^{7}$

4 John B. Taylor, "The Monetary Transmission Mechanism: An Empirical Framework", The Journal of Economic Perspective, 1995, Vol.09, No. 04, hlm. 11-26.

5 Ries Wulandari, "Do Credit Channel and Interest Rate Channel Play Important Role in Monetary Transmission Mechanism in Indonesia? A Structural Vector Autoregression Model", Procedia-Social and Behavioral Sciences, 2012, No. 65, hlm. 557-563.

6 M. Natsir, "Analisis Empiris Efektivitas Mekanisme Transmisi Kebijakan Moneter di Indonesia melalui Jalur Suku Bunga (Interest Rate Channel) Periode 1990-2007", Majalah Ekonomi, 2011, Vol. XXI, No. 2.

7 GhozaliMaski, "Studi Efektifitas Jalur-Jalur Transmisi Kebijakan Moneter dengan Sasaran Tunggal Inflasi (Pendekatan VAR)". Disertasi tidak 
Hasil pengujian melalui estimasi VAR menggambarkan keandalan penggunaan jalur suku bunga (RPUAB) dalam mengejar target kebijakan inflasi. Jalur nilai tukar Rupiah $(\$ / R p)$ pengaruhnya terhadap inflasi terlalu kecil dan cenderung terabaikan. Pada jalur kredit perbankan, kredit sektor pertanian paling dominan pengaruhnya terhadap inflasi. Chow (2004) menganalisis mekanisme transmisi kebijakan moneter di Singapura dimana jalur yang digunakan adalah jalur nilai tukar. ${ }^{8}$

Penelitian ini menggunakan analisis Vector Auto Regression (VAR). Melalui Impulse Response Function (IRF), penelitian ini ingin mengetahui bagaimana respon yang dihasilkan oleh shock dari nilai tukar terhadap output, suku bunga, harga dan nilai tukar itu sendiri. Variance Decompositions (VD) menunjukkan bahwa inovasi nilai tukar merupakan sumber yang lebih penting dari fluktuasi output, dibandingkan dengan shock suku bunga. Di akhir penelitian ditunjukkan bahwa variabel suku bunga bisa menjadi variabel endogen atau eksogen, hal tersebut terlihat dari impulse response yang tidak jauh berbeda.

\subsection{Kerangka Pikir}

Berdasarkan penjelasan teori dan konsep sebelumnya, maka dapat digambarkan kerangka pikir penelitian sebagai berikut:

Tabel 2. Mekanisme Transmisi Kebijakan Moneter dalam Kerangka Inflation Targeting di Indonesia

\begin{tabular}{|c|c|c|c|}
\hline Jalur MTM & $\begin{array}{l}\text { Variabel } \\
\text { Instrumen }\end{array}$ & $\begin{array}{c}\text { Sasaran } \\
\text { Operasional }\end{array}$ & $\begin{array}{c}\text { Sasaran } \\
\text { Akhir }\end{array}$ \\
\hline Jalur Moneter & M0 & M1, M2, KRDT, OG & \multirow{4}{*}{ INFLASI } \\
\hline $\begin{array}{c}\text { Jalur Suku } \\
\text { Bunga }\end{array}$ & \multirow{3}{*}{ RSBI } & $\begin{array}{c}\text { RPUAB, RDEPO, } \\
\text { RKRDT, OG }\end{array}$ & \\
\hline Jalur Kredit & & $\begin{array}{c}\text { RDEPO, CB, KRDT, } \\
\text { OG }\end{array}$ & \\
\hline $\begin{array}{l}\text { Jalur Nilai } \\
\text { Tukar }\end{array}$ & & $\begin{array}{c}\text { RDEPO, PSB, CAPIN, } \\
\text { KURS }\end{array}$ & \\
\hline
\end{tabular}

Keterangan:

$\begin{array}{llll}\text { MO } & \text { : Uang Inti } & \text { KURS } & \text { : Nilai Tukar } \\ \text { M1, M2 } & \text { : Uang Sekunder } & \text { RPUAB } & \text { : Suku Bunga PUAB } \\ \text { OG } & \text { : Output Gap } & \text { KRDT } & \text { : Kredit Perbankan } \\ \text { RSBI } & \text { :Suku Bunga SBI } & \text { CAPIN } & \text { : Capital Inflows } \\ \text { RDEPO } & \text { Suku Bunga } & \text { CB } & \text { : Cadangan Bank } \\ & \text { Deposito } & & \end{array}$

dipublikasikan, 2005, (Malang: Program Pasca Sarjana Universitas Brawijaya Malang).

8 Hwee Kwan Chow, "A VAR Analysis of Singapore's Monetary Transmission Mechanism", SMU Economics \& Statistics Working Paper Series, 2004.

RKRDT :
Suku Bunga
Kredit $\quad$ PSB $\quad \begin{aligned} & \text { Paritas Suku } \\ & \text { Bunga }\end{aligned}$

\section{METODOLOGI PENELITIAN 3.1. Sumber Data}

Jenis pendekatan yang digunakan untuk membahas permasalahan dalam penelitian ini adalah pendekatan kuantitatif. Penelitian ini merupakan studi kasus di Indonesia untuk periode antara tahun 2000 triwulan I sampai dengan tahun 2013 triwulan III. Data yang diperoleh bersumber dari Statistik Ekonomi dan Keuangan Indonesia (SEKI), Laporan Tahunan Bank Indonesia berbagai edisi, IMF Finance Statistics, dan publikasi dari Badan Pusat Statistik. Variabel- variabel yang digunakan dalam penelitian ini adalah sebagai berikut:

1. Inflasi (INF), yaitu inflasi berdasarkan IHK, dinyatakan dalam satuan persen.

2. Uang Inti (M0), yaitu uang kartal ditambah reserve money, dinyatakan dalam satuan miliar Rupiah.

3. Uang Sekunder (M1), terdiri atas uang kartal dan rekening koran,dinyatakan dalam satuan miliar Rupiah.

4. Uang Sekunder (M2), terdiri atas uang kartal, rekening koran dan uang kuasi, dinyatakan dalam satuan miliar Rupiah.

5. Output Gap (OG), yaitu selisih antara Produk Domestik Bruto (PDB) aktual dengan PDB potensial, dinyatakan dalam satuan miliar Rupiah.

6. Suku Bunga SBI (RSBI), dengan jangka waktu 1 bulan, dinyatakan dalam satuan persen.

7. Suku Bunga Deposito (RDEPO), dengan jangka waktu 3 bulan, dinyatakan dalam satuan persen.

8. Suku Bunga Kredit (RKRDT), kredit bank umum untuk investasi, dinyatakan dalam satuan persen.

9. Nilai Tukar (KURS), nilai Dollar Amerika terhadap Rupiah (\$/Rp).

10. Suku Bunga Pasar Uang Antar Bank (RPUAB), adalah tingkat suku bunga yang dikenakan oleh pihak bank kepada bank yang melakukan pinjaman, dinyatakan dalam satuan persen.

11. Kredit Perbankan (KRDT), kredit perbankkan pada berbagai sektor ekonomi, dinyatakan dalam satuan miliar Rupiah.

12. Capital Inflows (CAPIN), yaitu aliran modal yang masuk ke dalam negeri, dinyatakan dalam satuan juta Dollar Amerika. 
13. Cadangan Bank (CB), yaitu cadangan uang yang dimiliki bank, dinyatakan dalam satuan miliar Rupiah.

14. Paritas Suku Bunga (PSB), yaitu selisih antara suku bunga domestik (RDEPO) dengan suku bunga deposito perbankan di Singapura (SIBOR), dinyatakan dalam satuan persen.

\subsection{Model VAR}

Metode analisis data yang digunakan adalah analisis kuantitatif berupa Vector Auto Regression (VAR). Adapun model VAR dapat diformulasikan sebagai berikut:

(1) Mekanisme transmisi jalur moneter langsung

$$
\begin{aligned}
I N F= & C+a_{i} \sum M 0_{t-k}+a_{i} \sum M 1_{t-k}+ \\
& a_{i} \sum M 2_{t-k}+a_{i} \sum K R D T_{t-k}+ \\
& a_{i} \sum O G_{t-k}+a_{i} \sum I N F_{t-k}+\varepsilon
\end{aligned}
$$

(2) Mekanisme transmisi jalur suku bunga

$$
\begin{aligned}
I N F= & C+a_{i} \sum R S B I_{t-k}+a_{i} \sum R P U A B_{t-k}+ \\
& a_{i} \sum R D E P O_{t-k}+a_{i} \sum K R D T_{t-k}+ \\
& a_{i} \sum O G_{t-k}+a_{i} \sum I N F_{t-k}+\varepsilon
\end{aligned}
$$

(3) Mekanisme transmisi jalur nilai tukar

$$
\begin{aligned}
I N F= & C+a_{i} \sum R S B I_{t-k}+a_{i} \sum R D E P O_{t-k}+ \\
& a_{i} \sum P S B_{t-k}+a_{i} \sum C A P I N_{t-k}+ \\
& a_{i} \sum K U R S_{t-k}+a_{i} \sum I N F_{t-k}+\varepsilon
\end{aligned}
$$

(4) Mekanisme transmisi jalur kredit

$$
\begin{aligned}
I N F= & C+a_{i} \sum R S B I_{t-k}+a_{i} \sum R D E P O_{t-k}+ \\
& a_{i} \sum C B_{t-k}+a_{i} \sum K R D T_{t-k}+ \\
& a_{i} \sum O G_{t-k}+a_{i} \sum I N F_{t-k}+\varepsilon
\end{aligned}
$$

Model VAR tersebut di atas, ditampilkan hanya sebagian, yaitu pada persamaan inflasi saja karena fokus dari penelitian ini adalah untuk menganalisis efektivitas jalur-jalur transmisi kebijakan moneter dengan sasaran tunggal inflasi.

\subsection{Metode Analisis}

\section{a. Step 1: Uji Stasioneritas dan Derajat Integrasi}

Untuk menganalisis data yang bersifat time series perlu menguji ada tidaknya korelasi antar waktu. Pengujian ini akan dilakukan dengan unit roots test. Masing- masing variabel akan diuji, apakah variabel tersebut stasioner atau tidak. Apabila variabel yang diuji tidak stasioner pada tingkat level maka dilanjutkan dengan uji derajat integrasi.

\section{b. Step 2: Penentuan Lag Length}

Ada lima kriteria yang dapat digunakan untuk mengetahui berapakah jumlah lag yang sesuai untuk model yang diamati. Indikator criterion lag length tersebut adalah: LR, FPE, AIC, SC dan HQ. Hasil dari tahapan ini akan menunjukkan lag optimal yang direkomendasikan.

\section{c. Step 3: Analisis VAR}

Metodologi Vector Auto Regression (VAR) merupakan pemodelan persamaan simultan dimana kita memiliki beberapa variabel endogen secara bersamaan. Namun, masing-masing variabel endogen dijelaskan oleh lag, atau masa lalu, dari nilainya sendiri dan variabel endogen lainnya dalam model. ${ }^{9}$ Media yang digunakan untuk melakukan estimasi dalam model VAR adalah Impulse Response Function (IRF) dan Variance Decomposition. IRF digunakan untuk mengestimasi respon yang ditunjukkan setiap variabel ketika terjadi shock pada variabel tertentu. Sedangkan Variance Decomposition digunakan untuk mendapatkan informasi tentang kontribusi varian setiap variabel terhadap perubahan yang terjadi pada variabel tertentu.

\section{HASIL PENELITIAN}

\subsection{Pengujian Stasioneritas Variabel}

Prosedur yang digunakan untuk menguji suatu data stasioner atau tidak adalah dengan membandingkan antara nilai statistik dari DickeyFuller (DF statistic) dengan nilai kritisnya pada tingkat signifikansi tertentu (1\%, 5\%, dan 10\%). Jika nilai absolut dari statistik ADF lebih besar dibandingkan dengan nilai kritisnya, maka data tersebut berarti stasioner.
9 Damodar N. Gujarati dan Dawn C. Porter, DasarDasar Ekonometrika, Terj. Raden Carlos Mangunsong, Buku 2, Edisi 5, (Jakarta: Penerbit Salemba Empat, 2012). 
Tabel 3. Hasil Uji Akar-akar Unit Terhadap Variabel Penelitian dengan Pendekatan Augmented DickeyFuller (ADF)

\begin{tabular}{|c|c|c|}
\hline Variabe & ADF Statistik & ADF Kritis \\
\hline INF & $-5.467340^{*}$ & $-4.152511(1 \%)$ \\
\hline M0 & $-16.22604^{*}$ & $-3.502373(5 \%)$ \\
\hline M1 & $-16.08217^{*}$ & $-3.180699(10 \%)$ \\
\hline M2 & $-10.95531^{*}$ & \multirow{4}{*}{$\begin{array}{l}\text { Variabel RDEPO, } \\
\text { RKRDT, dan CAPIN } \\
\text { stasioner pada level. }\end{array}$} \\
\hline $\mathrm{OG}$ & $-39.28269 *$ & \\
\hline RSBI & $-4.181443^{*}$ & \\
\hline RDEPO & $-3.581224^{* *}$ & \\
\hline RKRDT & $-4.520854^{*}$ & \multirow{4}{*}{$\begin{array}{l}\text { Variabel INF, CB, } \\
\text { KURS, PSB, RPUAB, } \\
\text { dan RSBI stasioner } \\
\text { pada beda satu (1 }{ }^{\text {st }} \\
\text { different). }\end{array}$} \\
\hline KURS & $-7.013081^{*}$ & \\
\hline PRUAB & $-8.769732^{*}$ & \\
\hline KRDT & $-4.435195^{*}$ & \\
\hline CAPIN & $-4.809156^{*}$ & \multirow{3}{*}{$\begin{array}{l}\text { Variabel M0, M1, } \\
\text { M2, KRDT, dan OG } \\
\text { stasioner pada beda } \\
\text { dua (2 }{ }^{\text {nd }} \text { different). }\end{array}$} \\
\hline CB & $-3.502339^{* *}$ & \\
\hline PSB & $-3.835629^{* *}$ & \\
\hline
\end{tabular}

Catatan: * signifikan pada taraf $1 \%$

** signifikan pada taraf $5 \%$

Dari hasil uji akar-akar unit (unit roots test) menunjukkan bahwa variabel-variabel yang diteliti stasioner pada derajat yang berbeda-beda, maka dalam penelitian ini menggunakan model VAR indifference.

\subsection{Penentuan Lag Optimal}

Tabel 4. Hasil Uji Penentuan Lag Optimal

\begin{tabular}{|c|c|c|c|c|c|c|}
\hline Lag & Log & LR & FPE & AIC & SC & HQ \\
\hline 0 & - & NA & 8.91 & 184. & 185.19 & 184.87 \\
\hline 1 & - & 1051.96 & 1.72 & 164. & $172.19^{*}$ & 167.39 \\
\hline 2 & - & $263.32^{*}$ & $2.53^{*}$ & 160 & 175.90 & $166.61^{*}$ \\
\hline
\end{tabular}

Dari tabel 4 terlihat bahwa tanda bintang yang paling banyak berada pada lag 2. Hal ini menunjukkan bahwa lag optimal yang direkomendasikan adalah lag 2 .

\subsection{Analisis VAR (Variance Decomposition dan Impulse Response Function)}

Analisis Variance Decomposition dilakukan untuk mengetahui variabel-variabel mana yang mempunyai peran yang relatif penting dalam perubahan variabel itu sendiri maupun variabel lainnya. Analisis Variance Decomposition inflasi pada jalur moneter langsung menunjukkan bahwa varians M0 sebagai variabel instrumen, dan juga variabel-variabel lainnya yang bisa dijadikan sebagai sasaran operasional nilainya jauh lebih kecil daripada varians inflasi itu sendiri. Sedangkan pada jalur suku bunga terlihat bahwa varians RSBI sebagai variabel instrumen mempunyai nilai yang jauh lebih besar dari inflasi itu sendiri, selain itu varians RPUAB dan RDEPO memberikan kontribusi yang rata-rata meningkat dari waktu ke waktu.

Kemudian pada jalur kredit dan jalur nilai tukar memperlihatkan bahwa variabel Cadangan Bank (CB) dan Kredit (KRDT) pada jalur kredit dan variabel KURS pada jalur nilai tukar yang seharusnya memegang peranan penting pada jalur-jalur tersebut mempunyai nilai varian yang sangat kecil. Analisis Variance Decomposition inflasi pada keempat jalur ini menunjukkan bahwa jalur suku bunga lebih efektif dibandingkan dengan jalur-jalur lainnya. 
Tabel 5. Hasil Uji Variance Decomposition

\begin{tabular}{|c|c|c|c|c|c|c|c|}
\hline \multicolumn{8}{|c|}{ Jalur Moneter } \\
\hline Per & S.E. & D2M0 & D2M1 & D2M2 & D2KRDT & D2OG & DINF \\
\hline$\overline{c 1}$ & 2.139088 & 0.051547 & 0.327149 & 1.087827 & 9.073196 & 0.893136 & 88.56715 \\
\hline 5 & 3.519237 & 2.032630 & 0.310004 & 6.020843 & 17.51047 & 2.014474 & 72.11158 \\
\hline 10 & 3.636005 & 5.763224 & 0.589945 & 6.703470 & 16.62779 & 1.935270 & 68.38030 \\
\hline \multicolumn{8}{|c|}{ Jalur Suku Bunga } \\
\hline Per & S.E. & $\overline{\overline{\text { DRSBI }}}$ & DRPUAB & RDEPO & $\begin{array}{l}\text { RKRDT } \\
\end{array}$ & 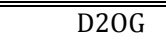 & DINF \\
\hline 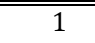 & 1.578380 & 7.829868 & 0.908110 & 0.123753 & 8.928700 & 40.076128 & 78.13344 \\
\hline 5 & 3.353119 & 31.86563 & 11.18409 & 18.24560 & 11.86966 & 1.988567 & 24.84646 \\
\hline 10 & 3.580901 & 30.85708 & 15.05190 & 17.21578 & 11.48383 & 1.961365 & 23.43005 \\
\hline \multicolumn{8}{|c|}{ Jalur Kredit } \\
\hline Per & S.E. & $\begin{array}{c}\text { DRSBI } \\
\end{array}$ & RDEPO & $\overline{\mathrm{DCB}}$ & D2KRDT & $\overline{\mathrm{D} 2 \mathrm{OG}}$ & $\overline{\overline{D I N F}}$ \\
\hline$\overline{c 1}$ & 1.666668 & 1011.50126 & 0.092113 & 101.750883 & $\begin{array}{l}1.685373 \\
\end{array}$ & 101.849253 & 83.12111 \\
\hline 5 & 3.102316 & 25.04413 & 33.52583 & 6.863338 & 2.032168 & 1.883357 & 30.65118 \\
\hline 10 & 3.420494 & 23.22559 & 38.16072 & 6.691585 & 2.596647 & 2.941838 & 26.38363 \\
\hline \multicolumn{8}{|c|}{ Jalur Nilai Tukar } \\
\hline Per & S.E. & $\overline{\text { DRSBI }}$ & RDEPO & DPSB & CAPIN & DKURS & DINF \\
\hline 1 & 1.747006 & 14.38382 & 0.118061 & 11.60723 & 0.861570 & 1.533756 & 71.49556 \\
\hline 5 & 3.430109 & 43.91374 & 22.40516 & 6.327946 & 0.860827 & 1.290615 & 25.20171 \\
\hline 10 & 3.765087 & 37.86463 & 21.85966 & 11.54744 & 2.832079 & 1.584906 & 24.31129 \\
\hline
\end{tabular}

Analisis Impulse Response dilakukan untuk melihat respon suatu variabel ketika terjadi shock (kejutan/goncangan) pada variabel lainnya. Analisis Impulse Response inflasi pada jalur moneter langsung menunjukkan lemahnya respon inflasi terhadap shock M0 yang menjadi variabel instrumen pada jalur ini dan juga terhadap variabel M1 dan M2 yang merupakan variabel penting pada jalur ini. Shock satu standar deviasi variabel M0 pada periode pertama direspon positif oleh inflasi hanya sebesar 0,05\%, kemudian pada periode-periode berikutnya direspon negatif, pada periode keenam mendapatkan respon sebesar -0,36\%. Respon inflasi terhadap shock satu standar deviasi variabel M2 sebesar $0,22 \%$ pada periode pertama dan respon terkuat hanya sebesar $-0,52 \%$ pada periode keempat. 
Gambar 1. Respon Inflasi terhadap Variabel-variabel pada Semua Jalur

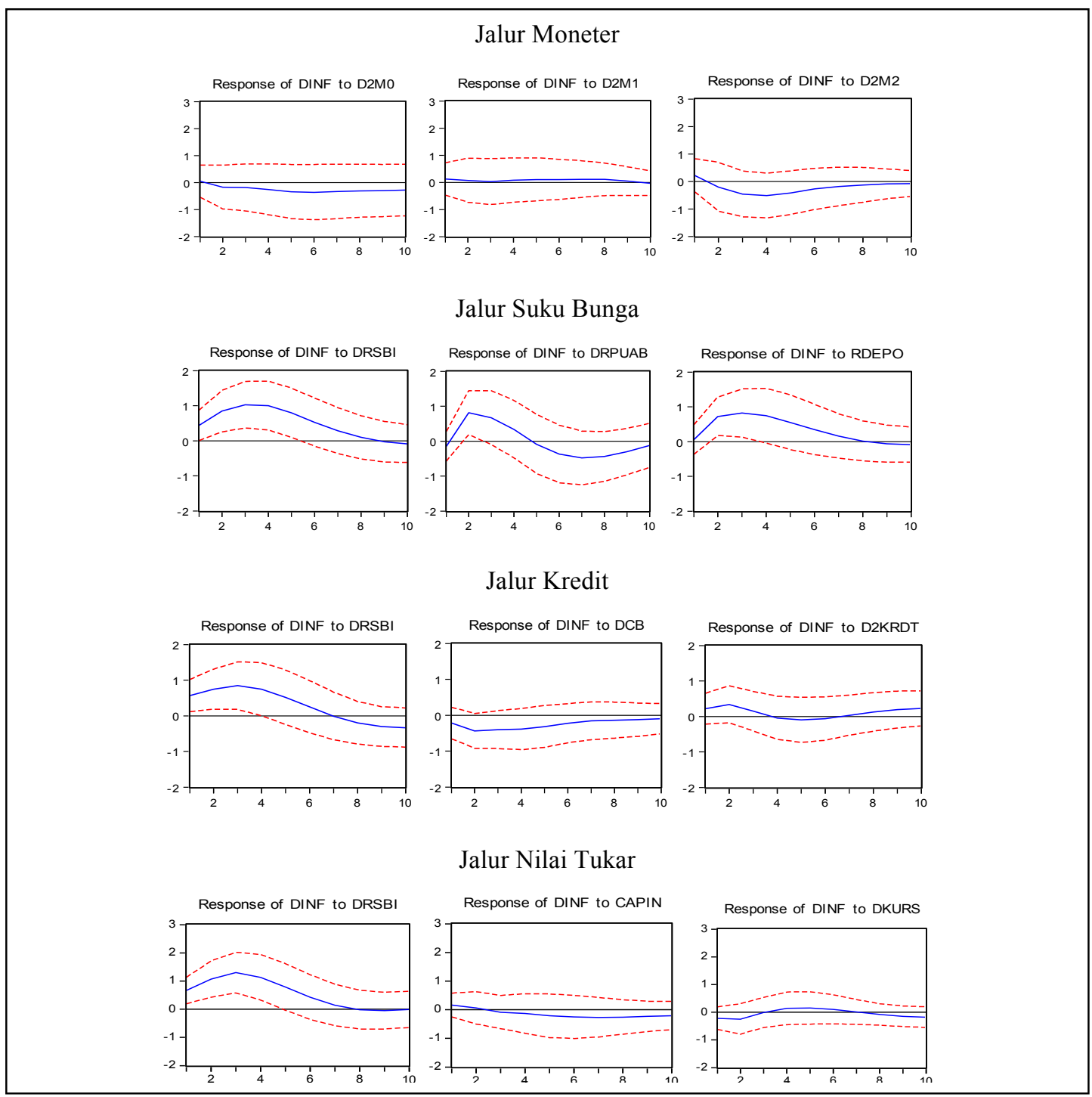

Pada jalur suku bunga terlihat bahwa shock RSBI sebagai variabel instrumen direspon positif dan sangat kuat oleh inflasi. Guncangan pada variabel lainnya, seperti RPUAB dan RDEPO juga direspon oleh inflasi dengan cukup kuat. Shock satu standar deviasi variabel RSBI pada periode pertama direspon positif oleh inflasi sebesar $0,44 \%$, kemudian terus meningkat hingga $1,02 \%$ pada periode ketiga. Respon inflasi terhadap shock satu standar deviasi variabel RPUAB dan RDEPO juga cukup kuat hingga diatas $0,8 \%$.

Shock variabel Cadangan Bank (CB) dan Kredit (KRDT) pada jalur kredit dan variabel KURS pada jalur nilai tukar yang seharusnya memegang peranan penting pada jalur-jalur tersebut hanya mendapat sedikit respon dari inflasi. Shock satu standar deviasi variabel CB mendapat respon terkuat pada periode kedua namun hanya sebesar $-0,44 \%$. Respon terkuat inflasi terhadap shock satu standar deviasi variabel
KRDT hanya sebesar $0,34 \%$ pada periode kedua. Shock satu standar deviasi variabel KURS mendapat respon terkuat pada periode kedua namun hanya sebesar $-0,25 \%$. Analisis ini menunjukkan bahwa kedua jalur tersebut dinilai kurang efektif dalam implementasi kebijakan moneter dengan sasaran tunggal inflasi di Indonesia. Melihat respon inflasi terhadap shock yang terjadi pada variabel-variabel yang terlibat dengan keempat jalur, maka bisa dikatakan bahwa jalur suku bunga lebih efektif bila dibandingkan dengan jalur-jalur lainnya. 
Berdasarkan uji Variance Decomposition pada jalur suku bunga didapatkan hasil bahwa varians RPUAB dan RDEPO mempunyai selisih yang sangat tipis, yakni hanya $2 \%$ saja, sehingga perlu mempertimbangkan hasil uji Impulse Response Function. Uji IRF pada jalur suku bunga menunjukkan bahwa shock RPUAB dan RDEPO mendapatkan respon sama-sama kuat dari inflasi, namun terlihat bahwa respon inflasi terhadap shock RPUAB lebih cepat daripada RDEPO. Respon terkuat dari shock RPUAB berada di periode kedua, sedangkan pada RDEPO berada di periode ketiga.

Gambar 2. Perbandingan Respon Inflasi terhadap RPUAB dan RDEPO

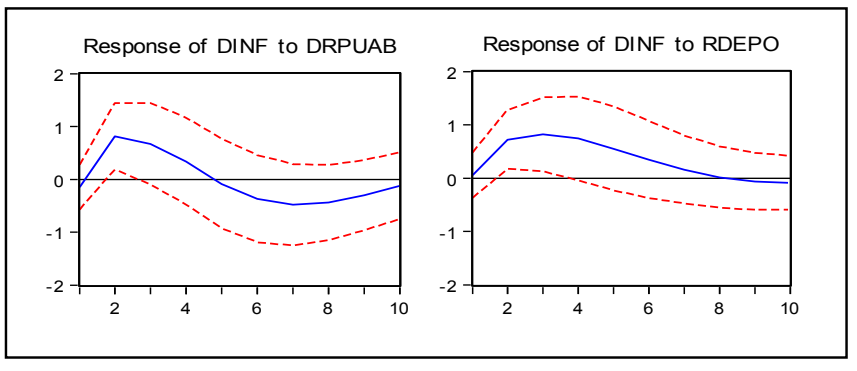

Dari hasil pengujian yang dilakukan maka dapat dinyatakan bahwa suku bunga pasar uang antar bank (RPUAB) sebagai variabel yang paling cocok digunakan sebagai sasaran operasional pada jalur suku bunga dalam kebijakan moneter dengan sasaran tunggal inflasi di Indonesia.

\section{PEMBAHASAN}

Berdasarkan hasil pengujian, jalur kuantitas uang (moneter) di Indonesia pada periode penelitian dinilai tidak cukup efektif. Hal ini disebabkan bahwa perekonomian Indonesia telah berubah dengan cepat dan semakin terbuka sehingga hubungan dengan negara lain semakin terintegrasi. Selain itu, sektor keuangan berkembang sangat cepat ke arah bekerjanya mekanisme pasar, timbulnya inovasi produk-produk keuangan baru, serta membaurnya operasi bank dengan lembaga-lembaga keuangan lainnya. Hal-hal tersebut telah menyebabkan proses penciptaan uang lebih banyak terjadi di luar kendali otoritas moneter dan proses money multiplier tidak lagi dapat diprediksi dengan baik, sehingga paradigma lama sistem pengendalian moneter dengan sasaran kuantitas tersebut menjadi semakin kurang relevan.

Jalur suku bunga (interest rate channel) menekankan pentingnya aspek harga di pasar keuangan terhadap berbagai aktivitas ekonomi di sektor riil. Kebijakan moneter yang ditempuh bank sentral akan mempengaruhi perkembangan berbagai suku bunga di sektor keuangan dan selanjutnya akan berpengaruh pada tingkat inflasi dan output riil. Hasil penelitian menunjukkan bahwa mekanisme transmisi melalui jalur suku bunga telah bekerja dengan efektif dan mengikuti paradigma uang pasif, yakni shock RSBI mempengaruhi suku bunga jangka pendek, dalam hal ini RPUAB sebagai sasaran operasional. Selanjutnya ditransmisikan ke sektor riil melalui pengaruh RDEPO dan RKRDT terhadap output gap dan selanjutnya terhadap inflasi sebagai sasaran akhir kebijakan moneter.

Kebijakan moneter oleh bank sentral, secara teori bisa mempengaruhi likuiditas perbankan (bank reserve) dan kemudian akan berpengaruh terhadap keputusan perbankan dalam pemberian kredit. Berdasarkan hasil pada penelitian ini, perubahan yang terjadi pada suku bunga SBI tidak banyak berpengaruh terhadap cadangan bank maupun jumlak kredit perbankan yang disalurkan. Hal ini bisa disebabkan oleh perilaku sektor perbankan dalam hal implementasi fungsi intermediasinya. Situasi ekonomi yang tidak menentu menjadikan bank lebih memilih memutarkan uangnya di pasar uang antar bank daripada menyalurkan kepada masyarakat, selain itu tingginya non performing loans (NPL) menjadikan perbankan lebih selektif dalam menyalurkan kredit.

Pengujian yang dilakukan menunjukkan bahwa mekanisme transmisi kebijakan moneter pada jalur nilai tukar kurang efektif dibandingkan dengan jalur suku bunga. Hasil studi ini berbeda dengan kondisi yang disyaratkan dalam teori purchasing power parity bahwa gejolak nilai tukar berpengaruh terhadap variablitas harga barang-barang yang diperdagangkan (tradeable) yang selanjutnya berpengaruh terhadap variabilitas inflasi, tidak relevan dengan kondisi perekonomian Indonesia dalam periode studi ini. Hal ini terjadi karena nilai tukar rupiah terhadap dolar AS selain dipengaruhi oleh faktor ekonomi juga dipengaruhi oleh faktor non-ekonomi misalnya faktor sentimen pasar dan gejolak politik.

\section{KESIMPULAN DAN SARAN}

\subsection{Kesimpulan}

Berdasarkan hasil pengolahan data dan pembahasan pada bagian sebelumnya, maka penelitian analisis efektivitas jalur-jalur transmisi kebijakan moneter di Indonesia dapat disimpulkan sebagai berikut:

1. Di antara empat jalur transmisi kebijakan moneter, dalam hal ini jalur moneter langsung, jalur suku bunga, jalur nilai tukar, dan jalur kredit, jalur suku bunga merupakan jalur yang paling efektif dibanding dengan jalur-jalur lainnya. Analisis yang dilakukan melalui uji impulse response dan uji variance decomposition 
menggambarkan keandalan penggunaan jalur suku bunga dalam mencapai sasaran akhir inflasi, terlihat dari respon yang diberikan oleh inflasi dan varians dari variabel-variabel yang terlibat dalam jalur ini.

2. Suku bunga pasar uang antar bank merupakan variabel yang paling cocok digunakan sebagai sasaran operasional pada jalur suku bunga dalam kebijakan moneter dengan sasaran tunggal inflasi di Indonesia. Hasil uji impulse response pada jalur suku bunga menunjukkan bahwa shock RPUAB mendapatkan respon yang kuat dan juga cepat dari inflasi.

\subsection{Saran}

Dari hasil penelitian yang telah dilakukan, ada beberapa saran yang dapat diajukan, baik untuk pengembangan pengetahuan maupun untuk kepentingan praktis, antara lain:

1. Jalur suku bunga yang telah terbukti efektif dapat digunakan sebagai dasar dalam perumusan kebijakan sebagai upaya untuk meningkatkan efektivitas pelaksanaan kebijakan moneter di Indonesia.

2. Stabilitas suku bunga pasar uang antar bank sebagai sasaran operasional kebijakan moneter hendaknya perlu dijaga agar sasaran akhir berupa inflasi juga bisa terkendali.

\section{DAFTAR PUSTAKA}

Boediono. (1982). Ekonomi Makro. Seri Sinopsis Pengantar Ilmu Ekonomi, No. 2. Edisi Ketiga. Yogyakarta: Badan Penerbit Fakultas Ekonomi (BPFE) UGM.

Cavoli, Tony. (2010). "What Drives Monetary Policy in Post-Crisis East Asia? Interest Rate or Exchange Rate Monetary Policy Rules", Journal of Asian Economics, No.21, hlm. 456465.

Chow, Hwee Kwan. (2004). "A VAR Analysis of Singapore's Monetary Transmission Mechanism", SMU Economics \& Statistics Working Paper Series.

Gujarati, Damodar N. dan Dawn C. Porter, (2012). Dasar-Dasar Ekonometrika, (Terj. Raden Carlos Mangunsong), Buku 2, Edisi 5. Jakarta: Penerbit Salemba Empat.

Hakim, Lukman. (2001). "Penerapan Pentargetan Inflasi dalam Mekanisme Transmisi Kebijakan Moneter 1990.1-2000.4", Media Ekonomi, Vol. 7, No. 2.

Maski, Ghozali. (2005). Studi Efektifitas Jalur-Jalur Transmisi Kebijakan Moneter dengan Sasaran
Tunggal Inflasi (Pendekatan VAR). Disertasi tidak diterbitkan. Malang: Program Pasca Sarjana Universitas Brawijaya.

Natsir, M. (2011). “Analisis Empiris Efektivitas Mekanisme Transmisi Kebijakan Moneter di Indonesia melalui Jalur Suku Bunga (Interest Rate Channel) Periode 1990: 2-2007:1", Majalah Ekonomi, Vol. XXI, No. 2.

Taylor, John B. (1995). “The Monetary Transmission Mechanism: An Empirical Framework", The Journal of Economic Perspective. Vol. 09, No. 04, hlm. 11-26.

Warjiyo, P dan Solikin. (2003). Kebijakan Moneter di Indonesia. Seri Kebanksentralan No. 6. PPSK. Jakarta: Bank Indonesia.

Warjiyo, Perry. (2004). Mekanisme Transmisi Kebijakan Moneter di Indonesia. Seri Kebanksentralan No. 11. PPSK. Jakarta: Bank Indonesia.

Wulandari, Ries. (2012). "Do Credit Channel and Interest Rate Channel Play Important Role in Monetary Transmission Mechanism in Indonesia? A Structural Vector Autoregression Model", Procedia-Social and Behavioral Sciences, No. 65, hlm. 557-563. 